\title{
Application of Reward and Punishment in Improving Employee Performance in The Development Administration Section of The West Aceh Regional Secretariat
}

\author{
Tuti Zulita1)*, Said Achmad Kabiru Rafiie'1)\& Fadhil2)
}

1) State Administration Studies Program, Faculty of Social and Political Sciences, Universitas Teuku Umar, Indonesia

2) Head of Administration for Development of West Aceh Regent's Office, Indonesia

Received: August 30, 2021; Reviewed: August 31, 2021: Accepted: October 02, 2021

*E-mail:tutizulita86@gmail.com

\begin{abstract}
This paper aims to find out how to apply rewards and punishments in improving employee performance in the Development Administration of West Aceh Regional Secretariat. The problem is focused on the provision of Rewards and Punishments, which have not gone well. To approach this problem, I used the theoretical references from Nnaji-Ihedinmah and Egbunik. The data were collected through a descriptive approach using interview, observation and documentation techniques and analyzed qualitatively. The results of this study are that the application of rewards in the Development Administration section has not been carried out properly. The provision of rewards was not given since there was no budget for giving rewards to employees. The employees only got performance benefits and allowances from existing programs. Rewards in the form of appreciation, neither financial nor non-financial awards were ever given to employees. Thus it can conclude that the employees want the application of these rewards to improve employee performance to be more motivated in doing work. The application of punishment, both in the development administration and during the morning meeting, has been carried out but has not gone well, there were still many employees who do not comply with the regulations that have been made, so it is necessary to carry out a more in-depth evaluation and improve the implementation of the rules more effectively and efficiently.
\end{abstract}

Keywords: Employee Performance; Rewards \& Punishments; Local Government

How to cite: Zulita, T., Rafiie, S.A.K., \& Fadhil. (2021), Application of Reward and Punishment in Improving Employee Performance in the Development Administration Section of West Aceh Regional Secretariat, Jurnal Administrasi Publik (Public Administration Journal), 11(2), 206-215 


\section{INTRODUCTION}

A government agency requires effective and efficient human resources. Human Resources (HR) is an important factor both in organizations and in a government forum since human resources will be the driving force or determinant of a company's success, developed by (Suak, Adolfina, \& Uhing, 2017). Today's globalization competition is so high that an important point that must be seen from various $\mathrm{HR}$ activities is employee performance evaluation to see the ability of human resources and performance appraisal of these employees, developed by (Tangkuman, Tewal, \& Trang, 2015).

Achieving excellence for the company in the competition is the basis of how the resources owned by the company are managed. The managed resources certainly cannot be separated from the resource factors themselves, namely employees or labor. The company looks for someone's performance that depends on the ability, individual support, and high motivation in doing a job.(Solikah, Setyowati, \& Sanosra, 2016).

West Aceh Regency is one of the regencies in Aceh province, which has an area of $10,097 . \mathrm{km}^{2}$ and consists of $12 \mathrm{sub}$ districts. The government of West Aceh Regent's Office is a government that can be called the capital of another government which is led by a Regent who works in that Government. Therefore, West Aceh Regent's Office has to make a government office have high resources and also have to pay attention to the needs of its employees both in terms of job needs, salaries, promotions, work environment and work equipment in the government agency so that employees can provide maximum results.

Rewards are a remuneration or award given by the company to employees who have achievements or show the appropriate performance expected by the company (Sandy \& Faozen, 2017) developed by (Pradnyani, Rahmawati, \&
Suci, 2020). The provision of rewards not only such as salaries wages and which includes quantitative elements but also includes gifts that are not in the form of money, such as providing opportunities to improve careers, providing opportunities to carry out great responsibilities, providing decent quality in the organization and providing opportunities for learning and developing, (in NnajiIhedinmah and Egbunike 2015) developed by (Putri Kentjana \& Nainggolan, 2018). In an organization, rewards can be divided into two parts (Mais, Liando, and Pangemanan 2019) namely: first, intrinsic reward, this type of reward is included in rewards that regulate themselves or received by employees for themselves, such as flattery, praise, and congratulations felt by employees as a form of recognition to themselves so that they can give satisfaction to themselves. Second, extrinsic rewards, this type of reward comes from the organizational environment itself; this reward is divided into three (3) parts: a) direct compensation (basic salary, overtime and leave, basic wages, receiving a share of profits, performance bonuses), b) indirect compensation (protection programs, additional services and income, and providing payment for time not working), and c) non-financial rewards, this nonfinancial award can be seen such what is chosen as a work assignment, personal secretary, equipment needed for the office, provided parking space needed by employees, given a good position.

The organization found the term incentive, which can be interpreted as an award in the form of material or nonmaterial to be given to employees from the organization's leadership, according to (Amri 2019).

In addition to giving rewards, leaders must also be firm in punishing employees who do not obey the rules. Based on Mangkunegara (2000), Punishment is a threat of punishment that aims to correct 
employees who break the rules, maintain applicable regulations and provide lessons developed by employees. (Primary, Widarko, \& Slame)The provision of punishment is basic so that employees can feel the deterrent effect of violating the rules, such as not coming to the office without a permit notification, not attending the morning ceremony and not being disciplined in coming to the office at the appointed time. The provision of punishment takes various forms according to the violations committed by the employees and the punishment given according to what has become a regulation set by a government agency. With the punishment, the workers will know the good and bad behavior, so they will not repeat the mistake based on their opinion(Sembiring \& Sandra, 2021). Types of Punishment can be described in several types based on Rivai (2013), as follows: Light punishment (oral reprimand to the employee concerned, an unsatisfied statement in writing and written warning), Moderate punishment (delay in giving salary that has been adjusted to the schedule, reduction in salary by agency regulations, delays in awarding ranks or promotions. Severe punishment (release from position, demotion or demotion, termination of work at the employer's wish, deciding not to work at the agency concerned).

One of the ways to achieve the goal of success of a government agency is by implementing rewards and punishments to improve employee performance. In-Law no. 5 of 2014, Article 82 is regulated concerning the State Civil Apparatus (ASN). For punishment regulations, it is regulated in government regulation no. 53, of 2010, regarding the punishment of civil servants, can realize it by enforcing civil servant discipline. Work discipline is compliance and obedience to the rules that have been set. If these regulations are not obeyed and commit violations, they will receive disciplinary sanctions. With the existence of this law, it can be seen how the implementation of the regulation is carried out strictly and firmly be based on the law (Harahap, Hasibuan, \& Watrianthos, 2020). Performance is a person's expertise in a particular field as an achievement that a person has in carrying out his duties and work given by his superiors to be carried out effectively and efficiently, according to (Hadari Nawawi, 19) developed by (Sustainable \& Firdausi, 2016) and (Heryanto, 2021).

Many previous researchers have conducted researches on this question, such as a previous study conducted by Meyrina (2017) entitled "Implementation of Rewards and Punishments on Employee Performance in the Ministry of Law and Human Rights." This study used a qualitative method. From the conclusion of this study, the implementation of reward and punishment has not balanced running together, which impacts employee careers. So far, gave rewards to outstanding employees in the form of placards, certificates, so employees felt that they had not shown justice and were not by the aim of increasing enthusiasm. In increasing motivation for employee performance, according to(Meyrina 2017).

The previous study also conducted by Lestari and Firdausi (2016) entitled "Implementation of rewards and punishments on employee performance within the Ministry of Finance in an effort to improve employee discipline (Studies at the State Treasury Service Office/KPPN, Kudus)." This study used a qualitative method. This study indicates that after the implementation of reward and punishment, the discipline of KPPN Kudus employees was increasing, both in time discipline and action discipline. The increase in time discipline in the actions of KPPN Kudus employees can be seen from the increased discipline and work order of KPPN Kudus employees, as well as the accuracy and speed of time of KPPN Kudus employees in 
carrying out work (Lestari \& Firdausi, 2016).

The researcher conducted a different study from previous research. In this case, the researcher researched reward and punishment in improving the performance of employees in the Development Administration Section of West Aceh Regional Secretariat. The provision of rewards in the development administration section is not by the work done by the employees. Many employees who work outside working hours, such as employees, have to continue their work at home and the workload is very heavy. However, in the Development Administration Division, the provision of rewards was not made well. Giving rewards is still seen from the position obtained by the employee, not from work done by the employee himself, so that employees can feel dissatisfied with the work done with the salary or bonus earned. And it is same as giving punishment to employees who do not go well, where it can be seen that there are still many undisciplined employees who go to work hours and follow the Ceremony every Monday. The punishment given to employees who violate the regulations has not provided a deterrent effect to employees. The data obtained by researchers where the researchers observe and are directly involved with employees in the Development Administration Section. Therefore, researchers were interested in examining whether the application of reward and punishment can improve employee performance.

The formulation of the problem in this study is how to apply Reward and Punishment to employees in the Development Administration Division and how to provide punishment to employees who do not attend the ceremony every Monday morning at West Aceh Regional Secretariat. This study aims to determine Reward and Punishment for employees in the West Aceh Stdakab Development Administration and Punishment for employees who do not attend the ceremony every Monday morning. The significance of the study is to improve employee performance and improve employee discipline by Reward and Punishment in the Development Administration Section of West Aceh Regional Secretariat.

\section{RESEARCH METHODS}

This study was a qualitative descriptive method. This study used a descriptive approach that describes an object in this study, such as applying rewards and punishments in improving employees' work in the development administration of the West Aceh Regional Secretariat. The data were analyzed using qualitative methods. Based on (Sumampow, Koleangan, \& Lengkong, 2019)

The data collection technique was carried out in this qualitative study using several techniques stated by Creswell (2008) developed by (Arisman, Sihotang, \& Sinaga, 2021). Some of the techniques used were: Identifying research topics. The researchers first identified the research topics to make it easier for researchers who were the basic foundation of every research activity. Reviewing the literature, the researcher assessed previous findings to provide accurate and useful information to serve as a reference for researchers and selecting participants/objects to obtain accurate data, which amounted to 8 people from the head of the section to the honorary employee and the head of the West Aceh Secretariat to provide the data needed by researchers.

To get accurate data, researchers collected data using observation techniques where researchers were directly involved with employees who worked in the development administration section. Researchers conducted interviews by asking these employees directly from each of the answers from the informants to get an accurate conclusion. And the data were analyzed using a comparative 
descriptive technique and then analyzed through data reduction, data display (presentation of data), and drawing conclusion /verification.

\section{RESULTS AND DISCUSSION}

\section{Application of Rewards in Development Administration in Improving Employee Performance}

To improve the performance of employees, aside from providing salaries to employees every month, also provided work performance allowances; the provision of performance allowances was around for a long time based on article 19 paragraph 1 and 2 of government regulation number 7 of 1997 concerning employee salary regulations as already three years ago. It changed it ten times. Then it is regulated in government regulation Number 11 of 2011 . If there is a strong reason, civil servants can be given allowances, and if applicable to certain civil servants, it is regulated by presidential regulation.

In the development administration section, the provision of work performance allowances was seen based on the position and rank held by the employee, whether they have a large workload or not. The following is a list of employees in the administrative division of rank development and their positions:

Table 1. List of employees and their positions

\begin{tabular}{lll}
\hline \multicolumn{1}{c}{ Name } & \multicolumn{1}{c}{ Level/GOAL } & \multicolumn{1}{c}{ Position } \\
\hline Syamsul Rizal, ST & Kindergarten stylist. IIII/d & Head of.Adm. Development \\
Fadhil, ST & Kindergarten stylist. IIII/d & Ksb. Program control \\
Nasri Risma, SKM., M. Kes & Kindergarten iIII/d & Ksb. Evaluation and reporting \\
Fasrial, SE & PenataIII/c & Ksb. Programming \\
Zulmia Maivita Devi, ST & PenataIII/c & Programming staff \\
Syahfridar Yani & Kindergarten manager. III/d & Evaluation and reporting staff \\
Sahlan Reza Muzys & Kindergarten Manager. III/d & Programming staff \\
Neri Darmiati & THL & Staff \\
\hline
\end{tabular}

Source: Development Administration Bagian

From table 1, it can see that the provision of performance achievement allowances is based on the position obtained; the higher the position, the higher the work performance allowance obtained. Work performance allowances are only given to employees, do not apply to the honorary employee.

Table. 2 Employee performance allowance

\begin{tabular}{|c|c|c|c|}
\hline Name & Level/GOAL & Position & Monthly Amount \\
\hline Syamsul Rizal, ST & $\begin{array}{l}\text { Kindergarten } \\
\text { stylist. IIII/d }\end{array}$ & $\begin{array}{l}\text { Head of Division. Adm. } \\
\text { Development }\end{array}$ & $2,500,000$ \\
\hline Fadhil, ST & $\begin{array}{l}\text { Kindergarten } \\
\text { stylist. IIII/d }\end{array}$ & Ksb. Program control & $1,500,000$ \\
\hline Nasri Risma, SKM., M. Kes & Piñata TK.iIII/d & Ksb. Evaluation and reporting & $1,500,000$ \\
\hline Fasrial, SE & PiñataIII/c & Ksb. Programming & $1,500,000$ \\
\hline Zulmia Maivita Devi, ST & PiñataIII/c & Programming staff & 800,000 \\
\hline Syahfridar Yani & $\begin{array}{l}\text { Kindergarten } \\
\text { manager. III/d }\end{array}$ & Evaluation and reporting staff & 750,000 \\
\hline Sahlan Reza Muzys & $\begin{array}{l}\text { Kindergarten } \\
\text { Manager. III/d }\end{array}$ & Programming staff & 750,000 \\
\hline
\end{tabular}

Source: Development Administration Bagian

From table 2, it can be seen that the higher the position and class owned, the higher the work performance allowance given. From the achievement allowance income obtained, there are other deductions such as absenteeism deductions where the deduction was calculated in three days of absent employees both 
morning, afternoon and evening, so it was calculated in one allowance deduction, allowance deductions in one time can be seen from how many day allowances received by employees based on the position they have. Then there were $4 \%$ PBJS dues deductions, 2.5\% zakat, PS 21 income tax cuts (15*5/15\%), 1\% and $4 \%$ BPJ deductions to the net allowances received by employees based on the remainder of the deductions.

Giving rewards is an effort to create a feeling of being recognized in the work environment, which relates to aspects of the relationship between workers and aspects of compensation. Rewards were given as gifts or bonuses as someone's achievements. Rewards can take many forms, such as words of praise to employees who have done a good job, according to(Agiwahyuanto, Widianawati, \& Wulan, 2020). Giving rewards showed that improving employee performance and employee behavior was to improve and accelerate the work assigned to employees to carry out the targets and goals to be achieved effectively and efficiently.

The provision of rewards in the development administration section to employees with a large workload is not given, either in bonuses, rewards, awards or appreciations. Employees who have a lot of workloads are the same as those who don't have a workload. After the researchers researched informants by asking how to apply rewards in improving employee performance, some informants said that there was no reward in the development administration department in bonuses, promotions, praise, and appreciation; employees only received work performance allowances.

According to the informant, the Head of the Development Administration Division said that the award was not given since devoted no budget to providing rewards. Therefore, employees who have a large workload do not get bonuses other than employee benefits.
According to a staff informant, Sahlan said that in the past, in the development administration section, there were rewards in the form of bonuses from the leadership to motivate employees if the employees did a good job and achieved the predetermined targets. Still, the reward only lasted until 2006 after giving that nothing anymore, clarity is no longer given since it did not get a budget anymore to specialize in giving rewards to employees. Now only getting allowances from employee performance and allowances from existing activities, every development administration carrying out activities would receive allowances from these activities. Before the occurrence of Covid-19, each activity carried out received an allowance of 500 thousand in one activity. However, after Covid-19, the benefits from activities only get 50 thousand for each activity carried out. And given in 1 (one) year divided equally to each employee. In this case, no allowance or bonus exceeds that of other employees, whether the employee had a large workload or an employee who had only a small workload.

Several employee informants in the development administration section said that employees needed the provision of rewards, both bonuses, promotions and appreciations since with these rewards they could improve employee performance, employees were more enthusiastic in doing work. They would be motivated to do work, so that would do the work. It did not feel like a burden.

So from these results, we can conclude that employees want the application of rewards to employees who have a lot of workloads, such as employees who have to work overtime in completing their work, so that employees will be more motivated in doing their jobs and will further improve their performance. Feel appreciated for the work done so that will complete the work given based on the set time. 
Tuti Zulita, Said Achmad Kabiru Rafiie \& Fadhil, Application of Reward and Punishment in Improving

Implementation of Punishment in Development Administration Section in Improving Employee Performance

The provision of punishment (punishment) aims to control employees to perform better, submit and obey the rules that have been set. When an employee violates the rules, would imposed punishment. Punishment was given as a threat to employees to correct employees who violated the rules. In the administrative development section, the punishment had been applied but there were still employees who violated the rules, so they had not implemented the punishments properly. Time discipline had become a common problem in every government agency, one of which is in the West Aceh regent's office in West Aceh Regional Secretariat Development Administration. By the rules applied at West Aceh regent's office, employee entry hours were at 08:00, but employees in the development administration department were often late, and some were not even present. Likewise, with the noon hour when employees enter at 13:30, many employees still did not arrive on time. Some even did not return to the office even though they had implemented a picket schedule for employees during the day. The following is the schedule for the picket of employees in the development of the Administration Section:

Table 3. Schedule of picket officers

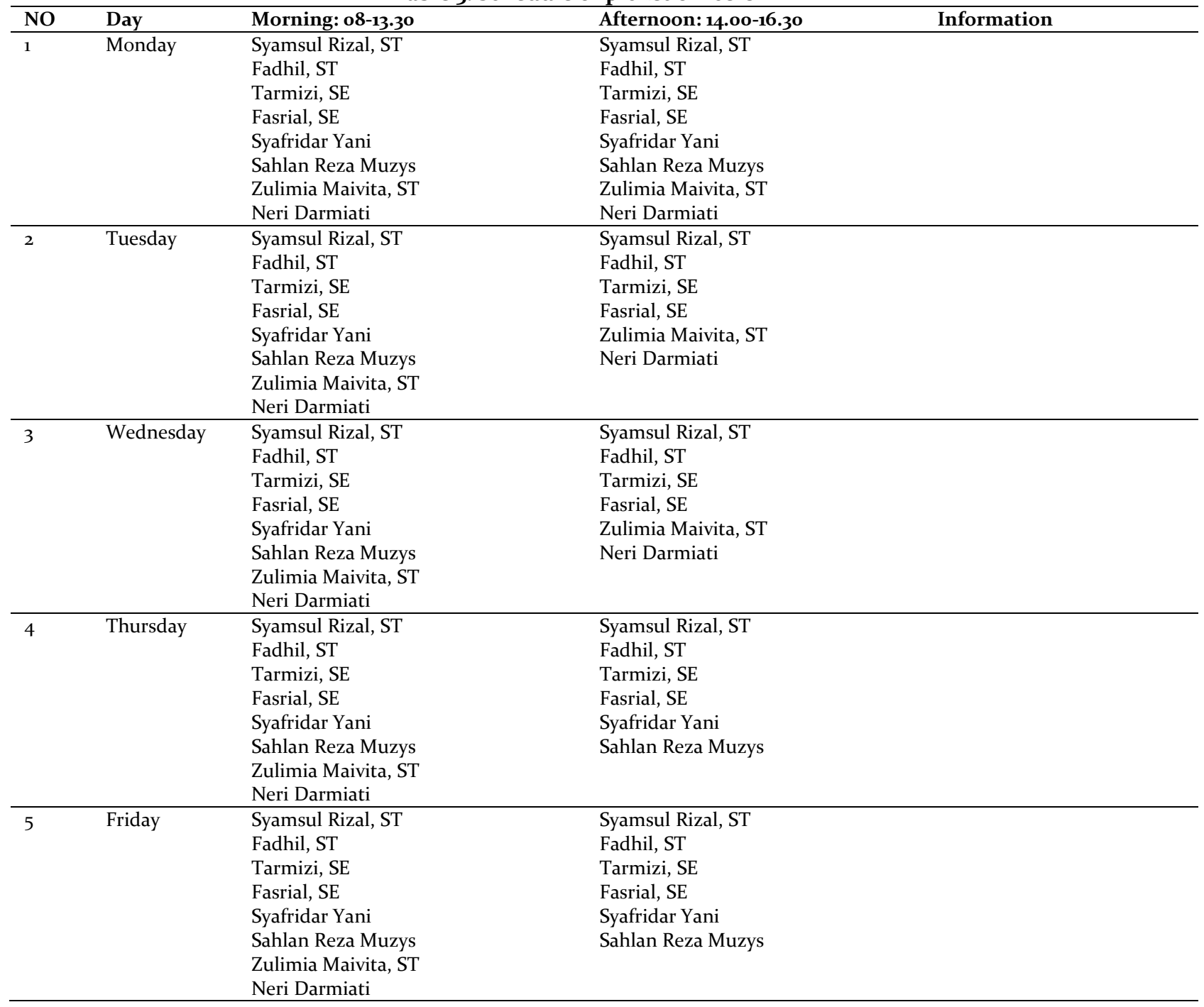


Following the results of joint research with informants in the development administration section, punishments had been carried out on employees who violated the regulations, giving the punishment in the form of verbal warnings to employees who did not comply with regulations and cutting employee performance allowances based on absenteeism. There are 3 (three) absent employees, then 1 (one) time deduction of the allowance will be calculated, such as: if the employee does not come to the office from morning to evening, will calculate the allowance deduction once. The allowance deductions were based on the position or class held since each employee receives different allowances. Other verbal reprimands such as employee discipline, If the employee was not disciplined in entering working hours, the leader only gives a verbal warning; will give no deductions or punishment other than a warning. Written reprimands were not given to employees such as letters of reprimand since feared that giving such reprimands will hurt employees such as jealousy of other employees or employee discomfort in doing work so that it will hinder the completion of work later on, therefore only giving verbal warnings and verbal warnings are often made to employees.

From the results of this study, we can conclude that the implementation of punishments in the development administration section had been carried out but had not gone well, seen from the number of employees who still violated the rules that have been made. The leaders were strictly required to further increase the punishment given to employees who do not comply with regulations to improve discipline and compliance with regulations. With the punishment, it is expected to motivate in improving employee performance.

\section{Implementation of Punishment in Improving Discipline Ceremony on Monday at the Regional Secretariat of West Aceh}

At West Aceh Regional Secretariat government agency, before the pandemic of covid-19, they held a morning ceremony every day. Leaders can see and check the discipline of employee time and employee absences where employees make direct attendance when attended morning ceremonies. This regulation was very good if applied continuously since employees would be disciplined during work hours with this rule. After the Covid-19 outbreak, the West Aceh Regional Secretariat government agency only held a morning rally on Monday to avoid crowds and comply with health protocols. After the researchers conducted research, they saw that there were still many employees who did not attend the morning ceremony on Monday due to the employee's delay in coming to the office.

The results of the study conducted by the researcher to the informant of the head of the regional secretariat of West Aceh Regency, he stated that the application of punishment to employees who did not attend the morning ceremony on Monday had been given punishment with an oral warning, the supervisor of the ceremony every Monday provided input and guidance. In addition, employees who did not attend the ceremony 3 (three) times a month would have their work performance allowance deducted. Calculated the deductions based on the allowances received; allowances deductions were calculated as one deduction with the absence of employees attending three ceremonies. If did it, the employee would be subject to other sanctions (punishments) such as delaying the receipt of the employee's salary and giving a warning letter to the employee. If employees received 3 (three) warning letters, they would be transferred to other agencies and demoted from their positions; it was done 
to improve employee discipline and create a high sense of responsibility to employees. The form of punishment rules given to employees was in the form of oral and written regulations.

From this description, the punishments for employees who did not follow the ceremony had been done well. However, the awareness and responsibility of employees were still weak in complying with the regulations that have been set. The work and rules were obligations for employees, so that they must be obeyed and implemented.

The provision of punishment given was seen from the violations committed by employees as stated in theory (Rivai, 2013) developed by (Wirawan \& Afani, 2018)(1) Minor penalties such as a verbal warning to the employee concerned, an unsatisfied statement in writing and written warning, 2) Moderate punishment such as delay in giving salary that had been adjusted according to the schedule, salary reduction following agency rules, delay in granting rank or promotion. 3) Severe penalties such as release from office, demotion or promotion, dismissal from work at the employee's wish, the decision not to work at the agency concerned, and decided not to work at the agency concerned.

\section{CONCLUSION}

The problem that occurred was the provision and application of rewards that had not to carried out properly for employees who had a lot of workloads such as employees who worked in the field of evaluation and reporting, preparation of programs that had no difference with employees who did not have workloads such as employees who were classified as working staff. In the field of program planning and program control. Therefore the employees felt dissatisfied with what was done with the results received. The application of punishment to employees who did not comply with the regulations was still not going well. There were still many employees who were late to the office either in the morning or in the afternoon, and there were even employees who did not return to the office at noon. The implementation of punishment for employees who did not attend the morning ceremony had not gone well; it can be seen that there were still many employees who did not attend the ceremony. The leaders were required to be more assertive in giving rewards and punishments to employees. With the affirmation of the leader of the employees, they could increase their resources and improve their performance. In addition, employees must increase a high sense of responsibility so that the rules they had set would be obeyed and implemented properly.

\section{REFERENCES}

A Agiwahyuanto, F., Widianawati, E., \& Wulan, W. R. ( 2020). Analisis Quality Assurance Penerapan Kebijakan Reward and . Jurnal Manajemen Informasi Kesehatan Indonesia , 37-43.

Amri, A. (2019). Pengaruh Reward Dan Punishment Terhadap Kinerja Karyawan Pada KSP Balota Kota Palopo. JURNAL OF ECONOMIC, MANAGEMENT AND ACCOUNTING , 53-59.

Arisman, A., Sihotang, H., \& Sinaga, D. (2021). Analisis Pemberian Reward dan Punishment untuk Meningkatkan Kinerja Guru dalam Melaksanakan Tugas Tambahan sebagai Wali Kelas di SMK Kristen Tagari Rantepao. Jurnal Pendidikan Tambusai , 1248-1256.

Harahap, J. M., Hasibuan, M. I., \& Watrianthos, R. (2020). Pengaruh Reward and Punishment (Penghargaan dan Hukuman), Koordinasi. Jurnal Ilmu Manajemen , 1-12.

Heryanto, S. M. (2021). Upaya Meningkatkan Kinerja Guru Dalam Pembelajaran. Jurnal Pendidikan Cerdik Cendekia , 83-96.

Lestari, A. W., \& Firdausi, F. (2016). Pelaksanaan Sistem Reward Dan Punishment Di Lingkungan Kementerian Keuangan. Jurnal Reformasi , 66-75.

Meyrina, R. S. (2017). Pelaksanaan Reward Dan Punishment Terhadap Kinerja Pegawai Di Lingkungan Kementerian Hukum Dan HAM. JIKH, 139-157.

Pradnyani, G., Rahmawati, P., \& Suci, N. (2020). Pengaruh Reward Dan Punishment Terhadap Motivasi Kerja Karyawan Pada CV Ayudya Tabanan Bali. Jurnal Manajemen dan Bisnis , 21-30. 
Pratama, A. P., Widarko, A., \& Slame, A. R. (n.d.). Pengaruh Reward Dan Punishment Terhadap Motivasi Kerja Karyawan Goldia Camilan Malang. e-Jurnal Riset Manajemen

Putri Kentjana, N. M., \& Nainggolan, P. (2018). Pengaruh Reward Dan Punishment Terhadap Kinerja Karyawan dengan Motivasi Sebagai Variabel. Journal Sustainable Tourism Industry for Economic Development, 973-997.

Sembiring, D. P., \& Sandra, E. (2021). The Effect Of Reward And Punishment To The Performance of PT. Telesindo Shop Tanjungpinang Employees. Journal of Business Managemen Review, 1-11.

Solikah, I., Setyowati, T., \& Sanosra, A. (2016). Pengaruh Reward, Punishment Dan
Motivasi. Jurnal Manajemen Dan Bisnis Indonesia , 91-105.

Suak, R., Adolfina, \& Uhing, Y. (2017). Pengaruh Reward Dan Punishment Terhadap Kinerja Karyawan Sutanraja Hotel Amurang. Jurnal EMBA , 1050-1059.

Sumampow, P., Koleangan, R., \& Lengkong, V. (2019). Implementation of Reward And Punishment In Improving Employees Work In Mandolang Sub-District Office. Jurnal EMBA , 4581-4590.

Tangkuman, K., Tewal, B., \& Trang, I. (2015). Penilaiankinerja, Reward, Dan Punishment Terhadap Kinerja. Jurnal EMBA: 884-895.

Wirawan, A., \& Afani, I. N. (2018). Pengaruh Rewarddan Punishment Terhadap Kinerja Dan Motivasi Karyawan Pada Cv Media Kreasi Bangsa. Journal of Applied Business Administration , 76-91.6-91. 